\title{
Enhancement of Sugarcane Productivity through STCR based Balanced Fertilization
}

\author{
M. Vijayakumar ${ }^{1 *}$, M. Thirunavukkarasu ${ }^{2}$, \\ R. Dhanasekara Pandian ${ }^{3}$ and P. P. Mahendran ${ }^{4}$
}

\author{
${ }^{1}$ Regional Research Station, TNAU, Paiyur (635 112), Krishnagiri, India \\ ${ }^{2}$ Subject Matter Specialist, Krishi Vigyan Kendra, Gandhigram Rural Institute-DU, Dindigul, \\ Tamil Nadu, India \\ ${ }^{3}$ Subject Matter Specialist, Krishi Vigyan Kendra, TNAU, Tiruppur, Tamil Nadu, India \\ ${ }^{4}$ Agricultural College and Research Institute, TNAU, Kudumiyanmalai (622 104), \\ Pudukkottai, India
}

*Corresponding author

\section{A B S T R A C T}

\section{Keywords}

Sugarcane, Biofertilizers, Tillers, Millable cane, STCR, Fertility, Ustropept

\section{Article Info}

Accepted:

28 April 2020

Available Online:

10 May 2020
A soil survey was conducted during September 2011 in the sugarcane dominant tracts of Theni district Tamil Nadu to find the soil fertility status and link with different cane yield potentials. The soil samples were taken from 400 spatially distributed locations from a depth of $0-30 \mathrm{~cm}$ and analyzed for texture, $\mathrm{pH}, \mathrm{EC}$, Organic carbon, available N, P\&K and micronutrients viz., $\mathrm{Fe}, \mathrm{Mn}, \mathrm{Zn}$ and $\mathrm{Cu}$. The interpolated macro and micronutrients status shows a clear deficiency of available nitrogen in 96 percent of the soil samples and DTPA - extractable $\mathrm{Zn}$ deficiency in almost 60 percent of the regions surveyed. However, the available phosphorus and potassium contents were reported to be moderate to high in 90 percent of the samples. Based on the above results, a field experiment was conducted during March 2012 to validate the balanced fertilization package to attain a factory average sugarcane yield of $150 \mathrm{t} \mathrm{ha}^{-1}$ from the present average of $95 \mathrm{t} \mathrm{ha}^{-1}$ at Rajshree Sugars and Chemicals Ltd. (RSCL) farm. The soils were normal in soil reaction ( $\mathrm{pH}$ ), non-saline, low in SOC and available $\mathrm{N}$ while high in available $\mathrm{P}$ and $\mathrm{K}$ status. The DTPA extractable Fe, $\mathrm{Mn}$ and $\mathrm{Cu}$ were sufficient while $\mathrm{Zn}$ was deficient. The effect of balanced fertilization on yield attributes and cane yields were significant. Among the treatments, the STCR based fertilizer application $\left(\mathrm{T}_{6}\right)$ on par with $\mathrm{T}_{9}(\mathrm{RSCL}$ package) recorded significantly the highest cane yield and sugar yield of 128 and $17.04 \mathrm{t} \mathrm{ha}^{-1}$, respectively. Considering the $\mathrm{B}: \mathrm{C}$ ratio, among the treatments $T_{9}$ and $T_{10}$ (TNAU package) which was on par with increase the yield from $102 \mathrm{t} \mathrm{ha}^{-1}$ to $128 \mathrm{t} \mathrm{ha}^{-1}$ could be recommended. But a revised balanced fertilization package with $\mathrm{N}$ at 275 to $300 \mathrm{~kg}, 112.5 \mathrm{~kg} \mathrm{P}_{2} \mathrm{O}_{5}$ and $150 \mathrm{~kg} \mathrm{~K} \mathrm{O}_{2}$ along with $50 \mathrm{~kg} \mathrm{FeSO}_{4} \mathrm{ha}^{-1}$ and $5 \mathrm{t} \mathrm{ha}^{-1}$ bio-compost or any other organic manure with recommended bio-fertilizers such as phosphate solubilizing bacteria and arbuscular mycorrhizae (AM) has to be test verified to maximize sugarcane productivity. 


\section{Introduction}

Sugarcane (Saccharum officinarum L.) is a natural renewable agricultural resource that provides sugar, bio-fuel, fiber and manure besides many by products. The crop is grown mainly for manufacture sugar and for making gur and khandasari. It is one of the important commercial crops of sugar in the world (Anon, 2005). In India, sugarcane is grown under diverse agro climatic situations covering an area of 5.1 million ha with an annual production of 357.7 million tonnes and the average productivity is of 70 tonnes $\mathrm{ha}^{-1}$ (Economic Survey, 2013). In Tamil Nadu, sugarcane is cultivated to the extent of 0.31 million hectare (mha) with the production of 32.5 million tonnes of cane and an average productivity of 104 tonnes $\mathrm{ha}^{-1}$ (Season and Crop Report, 2015). Among the cane growing states, Tamil Nadu stands third in area and production, and first in productivity, which is about 35\% higher than the national productivity.

Fertilizers play vital role in production and productivity of sugarcane but continuous and indiscriminate use of $\mathrm{N}$ fertilizer and in adequate application of $\mathrm{P}, \mathrm{K}, \mathrm{S}$ and micronutrients result in imbalance in the supply of plant nutrients to sugarcane. Subsequently, most of the productive soils become unproductive (Srivastava et al., 2013). Use of chemical fertilizers in combination with organic manure is essentially required to improve the soil health. The fertilizers need to be applied according to soil and crop characteristics so that nutrient use efficiency and the crop yield levels are increased (Tiwari, 2002). The quantities of fertilizer for sugarcane varied in different regions depending upon the soil type, organic matter $(\mathrm{OM})$, and nutrient content of the soil (Plucknett et al., 1970). Most of soils in the country are low in $\mathrm{OM}$, generally containing less than $1.5 \%$ while 2.5 to $3.0 \% \mathrm{OM}$ are necessary for sustainable crop production (Bhander, 1998). Sugarcane is an exhaustive crop and depletes soil nutrient heavily. A sugarcane crop giving cane yield of $100 \mathrm{tha}^{-1}$ may removes about $130 \mathrm{~kg} \mathrm{~N}, 22 \mathrm{~kg} \mathrm{P}, 146 \mathrm{~kg}$ $\mathrm{K}$, and $30 \mathrm{~kg} \mathrm{~S}$ per hectare from soil besides other micronutrients and losses of nutrients from soil (Sammuels, 1965).

Application of fertilizers is one of the ways to minimize the yield gap of plant. In more recent times, a considerable gap between the potential and actual cane yields has been realized in different parts of Tamil Nadu and specifically in Theni district where the average yield $\left(88 \mathrm{t} \mathrm{ha}^{-1}\right)$ is lower than many other parts of the state (Balaji et al., 2006). In research trials and best maintained farmers field, average yield of sugarcane to the tune of $250 \mathrm{t}$ $\mathrm{ha}^{-1}$ were recorded. But, the district average yield of sugarcane only $88 \mathrm{t} \mathrm{ha}^{-1}$ with a sugarcane area of 7,510 ha.

Hence, this study was planned to develop a balanced fertilization package to increase the productive yield to $150 \mathrm{t} \mathrm{ha}^{-1}$. In this context, the present study on maximizing sugarcane productivity through soil nutrient database based balanced fertilization was taken up with objectives of the effect of balanced fertilization package on growth characteristics, nutrient content, yield and yield attributes and quality of sugarcane.

\section{Materials and Methods}

The Theni district is located in the foot of Western Ghats between $9^{\circ} 30^{\prime}$ and $10^{\circ} 12^{\prime}$ North latitude and $77^{\circ} 10^{\prime}$ and $77^{\circ} 42^{\prime}$ East longitude and 200-400 $\mathrm{m}$ above sea level in the plains. The base map of the district is given in Figure 1. It is bounded by Dindigul district in the north, Madurai in the east, Virudunagar district in the south and Kerala state in the west. The district has a total geographical area of 2,89,000 ha has a 
bimodal rainfall pattern and the mean annual rainfall was $765 \mathrm{~mm}$. The rainy season covers June to December and maximum rainfall $(50 \%)$ is received during North East monsoon from October to December followed by South West monsoon from June to September which contributes $25 \%$ of the annual rainfall.

The mean maximum, minimum and average air temperatures are $33.3,23.5$ and $28.5^{\circ} \mathrm{C}$ respectively. The soil sampling points were identified based on the soil variability, irrigation sources and previous year sugarcane yields (low <75: medium 75-100: high >100 tonnes $\mathrm{ha}^{-1}$ ) among the sugarcane division of M/s Rajshree Sugars and Chemicals Limited (RSCL), Vaigai dam. The coordinates along with the altitude of these sampling points were marked using Global Positioning System (GPS). Four hundred surface soil samples (0$30 \mathrm{~cm}$ ) were collected at random @ 50 samples per division with a range of 4-10 samples per revenue village of eight divisions of RSCL, Theni district.

\section{Experimental site and soil characteristics}

A field experiment was conducted during 2012-2013 with sugarcane (var. Co 86032) as test crop to validate the balanced fertilization package for maximizing sugarcane productivity at RSCL farm in Theni district of Tamil Nadu. Initial soil samples $(0-15 \mathrm{~cm})$ were collected from experimental plots, samples were air dried and ground to pass through a $2 \mathrm{~mm}$ sieve.

The soil was a calcareous sandy loam (Thulukkanur soil series Typic Ustropept) containing sand, silt and clay at the rate of $70.7,12.4$, and $16.8 \%$, respectively with $\mathrm{pH}$ 7.55 and EC $1.15 \mathrm{dS} \mathrm{m}^{-1}$. The soil had $7.4 \mathrm{~g}$ $\mathrm{kg}^{-1}$ organic carbon, available N $226 \mathrm{~kg} \mathrm{ha}^{-1}$, available P $43 \mathrm{~kg} \mathrm{ha}^{-1}$, available $\mathrm{K} 705 \mathrm{~kg} \mathrm{ha}^{-1}$, available $\mathrm{S} 4.6 \mu \mathrm{g} \mathrm{g}^{-1}$, and $0.9 \mu \mathrm{g} \mathrm{g}^{-1} \mathrm{Zn}$ contents. Also, cation exchange capacity (CEC) of the soil was $15.0 \mathrm{cmol}(\mathrm{p}+) \mathrm{kg}^{-1}$.
Treatment Details and Fertilizer Application

In the RSCL farm experimental site, sugarcane (Var. Co 86032) was grown with following the treatments were imposed.

In all the treatments, $10 \%$ recommended $\mathrm{N}$ and $50 \% \mathrm{P}$ were applied basally remaining 90 $\% \mathrm{~N}$ was applied in three equal splits @ $30 \%$ with $\mathrm{K} @ 20,40$ and $40 \%$ at $30^{\text {th }}, 60^{\text {th }}$ and $90^{\text {th }}$ days after planting. The remaining $50 \%$ of $\mathrm{P}$ was applied in 2 equal splits at $60^{\text {th }}$ and $90^{\text {th }}$ days after planting. The crop was harvested at maturity stage and yield attributes were recorded.

\section{Plant sampling and chemical analyses}

The effect of balanced fertilization package on growth characteristics number of tillers (120 DAP) and that of millable cane stalks, yield and yield attributes and quality character of sugarcane at harvest were studied. The index leaf samples $\left(3^{\text {rd }}-4^{\text {th }}\right)$ from top of plant cane stalks were collected from the sampled cane at $90^{\text {th }}, 150^{\text {th }}, 210^{\text {th }}, 270^{\text {th }}$ DAP and at harvest and separated into leaf blade and leaf sheath. Midribs were excluded from leaf blade and samples were dried at $70{ }^{\circ} \mathrm{C}$ and milled for nutrient analysis and analyzed for total $\mathrm{N}, \mathrm{P}$, $\mathrm{K}$, S, as per the crop logging procedure described by Lakmikantham et al., (1970).

Soil textural class was determined by hydrometer method and the $\mathrm{pH}$ and $\mathrm{EC}$ was measured with glass electrode in a 1:2.5 soil/water suspension (Jackson, 1973), Organic Carbon estimation by Walkley and Black (1934), available Nitrogen by Subbaiah and Asija (1956), available soil Phosphorus by Olsen's extractants of $0.5 \mathrm{M} \quad \mathrm{NaHCO}_{3}$ as described by Olsen et al., (1954) and estimated by Murthy and Riley method using ascorbic acid as reducing agent and as described by Watanabe and Olsen (1965) using spectrometer with red filter at $660 \mathrm{~nm}$ 
wave length. Available potassium was extracted with neutral $1 \mathrm{~N} \mathrm{NH}_{4} \mathrm{OAc}$ and then determined by flame photometer (Jackson, 1973) and available $S$ by turbidimetric method Williams and Steinberg's (1959) for soil and plant leaf. Micronutrient $\mathrm{Zn}$, was analyzed using atomic absorption spectrometry (PerkinElmer 3111) following Petersen (2000). Data were statistically analyzed by using analysis of variance (ANOVA) and the treatment differences were adjudged by Agres test.

\section{Assessment of juice quality criteria}

The bio-chemical parameters viz., brix \%, pol $\%$, purity $\%$ and CCS $\%$ were estimated in the laboratory as per the procedure outlined by Meade and Chen (1977). The analysis was performed on five stalk samples which were collected at the age of 12 months. The stalks were shredded using a cutter grinder. The shredded material was then mixed thoroughly and juice was extracted. The juice was clarified using lead acetate, filtered and polarization reading was taken using Polatronic Universal and the juice was analyzed for quality parameters.

The following parameters were recorded from the extracted juice:

Brix: It is the concentration (in grams solute per $100 \mathrm{~g}$ solution) of a solution of pure sucrose in water, having the same density as the solution at the same temperature. The Brix of the sample was estimated by brix hydrometer (Chen and Picon, 1972).

Pol: The pol of a solution refers to the concentration (in grams solute per $100 \mathrm{~g}$ solution) of pure sucrose in water having the same optical rotation as the sample at the same temperature. From the juice samples, the pol $\%$ (sucrose \%) was estimated by using polariscope (Chen and Picon, 1972).
Purity: It refers to the ratio of sucrose content to the soluble solids in juice. The $\%$ purity was calculated from the dividing of pol $\%$ by corrected brix and multiplied by 100 .

Commercial cane sugar (CCS): The CCS was calculated from the 'brix' and 'pol' \% using the following formula and expressed in $\%$. $[$ CCS $(\%)=(1.022 \times$ S $)-(0.292 \times$ B $)]$ where, $\mathrm{S}=$ Sucrose \%; B = Brix \% and 1.02 and 0.292 are constants

\section{Results and Discussion}

\section{Nutrients status of soil survey samples}

\section{Physico-chemical properties}

The soils of the Theni district as evaluated in the major blocks are acidic to alkaline in reaction with $\mathrm{pH}$ ranging from 4.70 to 9.2 with a mean value of 7.92. The variation in $\mathrm{pH}$ may be due to the inherent heterogeneity of soils occurrence of various soil types like red, mixed red and black and black soils within the division. With the increase of $\mathrm{pH}$ the availability of micronutrients decreased, which might be due to precipitation of micronutrients in alkaline soils. This was confirmed by correlation studies that showed the soil $\mathrm{pH}$ had significant and negative correlations with available iron ( $\mathrm{r}=-0.5184)$ and manganese $(r=-0.4426)$ contents. The total soluble salts expressed as electrical conductivity (EC) varied from 0.03 to 1.64 $\mathrm{dSm}^{-1}$ in the soils analyzed, invariably all the soil samples collected from the 8 divisions of sugarcane growing area recorded EC of less than $2 \mathrm{dS} \mathrm{m}^{-1}$ indicating that the soils are free from salinity.

The available status of organic carbon ranged from 0.4 to $14.6 \mathrm{~g} \mathrm{~kg}^{-1}$ with a mean value of $5.7 \mathrm{~g} \mathrm{~kg}^{-1}$. About 36 to 64 per cent of the soils from all the 8 divisions were found to have low organic carbon status $\left(<5.0 \mathrm{mg} \mathrm{kg}^{-1}\right)$. 
However, about 36 per cent of the soils from Theni and Bodi each were found to have higher organic carbon status.

\section{Available macronutrients}

The available nitrogen content of the soil samples varied from 69 to $448 \mathrm{~kg} \mathrm{ha}^{-1}$ with a mean value of $207 \mathrm{~kg} \mathrm{ha}^{-1}$ in different revenue villages of the sugarcane growing divisions. As shown in Table 1, the analytical results of the soil samples showed that almost all the soils from the 8 divisions covering an area of 4224 ha $(96 \%)$ were low in available nitrogen status ( $<280 \mathrm{~kg} \mathrm{ha}^{-1}$ ) based on the critical level of $280 \mathrm{~kg} \mathrm{ha}^{-1}$ fixed (Muhr et al., 1965). The low levels may be ascribed to several factors, such as lower organic carbon and high $\mathrm{pH}$. Soil available nitrogen had significant and positive correlation with organic carbon $(\mathrm{r}=$ $0.3994 * *)$ content. These findings are related with those of Sharma and Singh (2001) and Rakesh Kumar et al., (2009). The available phosphorus content of soil samples varied between 9 and $183 \mathrm{~kg} \mathrm{ha}^{-1}$ with a mean value of $55 \mathrm{~kg} \mathrm{ha}{ }^{-1}$. Among the 400 samples analyzed, about 90-95 per cent of the soil samples (3498 ha area) were found to be high in soil available phosphorus status ( $>22 \mathrm{~kg} \mathrm{ha}^{-}$ $\left.{ }^{1}\right)$. The invariably high $\mathrm{P}$ status of the soil may be due to continuous application of phosphotic fertilizer (DAP), bio-compost/green plus or rock phosphate enriched compost by the cane farmers of Rajshree sugar mills area as recorded in the farm survey conducted before the preliminary soil sampling study. Bali et al., (2010) also reported a similar trend in soils of Punjab where, about 45 per cent of the area is high in available $\mathrm{P}$ status. The available potassium content of soil samples ranged from 83 to $2010 \mathrm{~kg} \mathrm{ha}^{-1}$ with a mean value of 514 $\mathrm{kg} \mathrm{ha}^{-1}$. About 70 to 80 per cent of soils from 3267 ha of the major cane growing divisions of Theni district registered high status of available potassium (>280 $\left.\mathrm{kg} \mathrm{ha}^{-1}\right)$. The highest mean value of available $\mathrm{K}(636 \mathrm{~kg}$ $\mathrm{ha}^{-1}$ ) was recorded in P. C. Patti and the lowest mean value of $203 \mathrm{~kg} \mathrm{ha}^{-1}$ was recorded in Andipatti division of Theni district. Available potassium had a significant positive correlation with EC $\left(\mathrm{r}=0.2976^{*}\right)$, OC $(\mathrm{r}=$ $\left.0.2204^{*}\right)$ and available nitrogen $\left(r=0.2491^{*}\right)$ which was inalignment with the results reported by Bali et al., (2010).

\section{Available micronutrients}

The available iron content of soil samples varied from 1.4 to $129 \mathrm{mg} \mathrm{kg}^{-1}$ with a mean value of $12.99 \mathrm{mg} \mathrm{kg}^{-1}$. The highest mean value was found in Cumbum division (21.3 $\mathrm{mg} \mathrm{kg}^{-1}$ ) and lowest was found in Mailadumparai division (6.72 $\left.\mathrm{mg} \mathrm{kg}^{-1}\right)$. The Mailadumparai, Andipatti and P.C. Patti divisions had 46, 24 and 22 per cent of soil samples were deficient in available Fe. This might be due to precipitation of $\mathrm{Fe}^{2+}$ in higher $\mathrm{pH}$ of the sodic soils in these soils and this can be confirmed through the significant and negative correlation of soil $\mathrm{pH}$ with available iron $\left(\mathrm{r}=-0.5184^{*}\right)$ which was also reported by Verma et al., (2007). The available manganese content of soil samples ranged from 1.0 to $45.1 \mathrm{mg} \mathrm{kg}^{-1}$ with a mean value of $7.76 \mathrm{mg} \mathrm{kg}^{-1}$. The highest and lowest mean values of 13.4 and $3.73 \mathrm{mg} \mathrm{kg}^{-1}$ were recorded in Cumbum and Theni division respectively. A negative significant correlations of available $\mathrm{Mn}$ with $\mathrm{pH} \quad\left(\mathrm{r}=-0.4426^{* *}\right)$ and nonsignificant correlation with organic carbon $(\mathrm{r}=$ 0.0506) was also reported. Similar results were also reported in Lachimpur series of Jharkhand (Rakesh Kumar et al., 2009) which may be due to the formation of insoluble higher valent oxides of $\mathrm{Mn}$ at high $\mathrm{pH}$ (Naheed et al., 2010).

The available zinc content of soil samples ranged from 0.1 to $12.8 \mathrm{mg} \mathrm{kg}^{-1}$ with a mean value of $1.6 \mathrm{mg} \mathrm{kg}^{-1}$. More than 50 per cent of soil samples were found to be deficient from all divisions. A significant and negative 
correlation $\left(\mathrm{r}=-0.3050^{*}\right)$ with $\mathrm{pH}$ indicated the availability of $\mathrm{Zn}$ decreases with increase in soil $\mathrm{pH}$. The available copper content of soil samples from all the cane divisions of sugar mill ranged from 0.5 to $11.1 \mathrm{mg} \mathrm{kg}^{-1}$ with a mean value of $2.42 \mathrm{mg} \mathrm{kg}^{-1}$. All the divisions recorded sufficient in status of available copper content. It showed a significant and positive correlation with organic carbon, available nitrogen, phosphorus and potassium, DTPA-Fe and Zn Table 2. The increased availability of $\mathrm{Cu}^{2+}$ may be due to the fact that, DTPA being organic chelating agent extracts micronutrient cations from different pools and the higher amount of organic carbon coupled with low $\mathrm{pH}$ values is further likely to increase the solubility of micronutrient cations (Talukdar et al., 2009).

\section{Effect of balanced fertilization of sugarcane on yield attributes}

\section{Number of tillers}

Tillering is an important physiological activity in sugarcane crop. The tiller production and their survival reflect on the total number of millable canes at harvest which ultimately reflects on cane yield. The effect of balanced fertilization on number of tillers of sugarcane at $120^{\text {th }}$ day after planting (DAP) was significant is given in Table 3 . The number of tillers of sugarcane varied between 158.3 ('000 ha ${ }^{-1}$ ) and 184.7('000 ha ${ }^{-1}$ ). The STCR based fertilizer application $\left(\mathrm{T}_{6}\right)$ recorded the highest number of tillers 184.7 ('000 ha-1), which was on par with $\mathrm{T}_{9}$ (RSCL package), $\mathrm{T}_{2}$ $(125 \% \mathrm{~N}+100 \% \mathrm{P} \& \mathrm{~K})$ and $\mathrm{T}_{10}$ (TNAU package).The results revealed that balanced fertilization package recorded the highest number of tillers due to lower rate of mortality and optimum nutrition. Also, balanced fertilizer application along with organic and bio-fertilizers, increase the rate of biosynthesis of various plant metabolites and physiological process in the plant system leading to increased rate of tiller formation as reported by Navnit Kumar (2012). The early application of $\mathrm{N}$ in three splits $\left(30^{\text {th }}, 60^{\text {th }}\right.$ and $90^{\text {th }}$ DAP) induced more vegetative growth and more production of number of tillering was reported by Srinivas et al., (2003). The While, $\mathrm{T}_{4}(100 \% \mathrm{~N}+50 \% \mathrm{P} \& \mathrm{~K})$ recorded the lowest number of tillers 158.3 ('000 ha' ${ }^{-1}$ ).

\section{Number of millable cane}

The number of millable cane is an important yield attribute in determining the ultimate cane yield in sugarcane (Table 3 ). The effect of balanced fertilization on number of millable cane was found to be significant and it's varied between 99.1 ('000 $\mathrm{ha}^{-1}$ ) and 122.7 ('000 ha $\mathrm{ha}^{-1}$ ). The STCR based fertilizer application $\left(\mathrm{T}_{6}\right)$ recorded the maximum NMC of 122.7 ('000 ha ${ }^{-1}$ ) which was on par with $\mathrm{T}_{9}$ (RSCL package) and $\mathrm{T}_{2}(125 \% \mathrm{~N}+100 \%$ $\mathrm{P} \& \mathrm{~K})$. The results revealed that balanced use of inorganic fertilizers (major-micronutrients), bio-compost and bio-fertilizers resulted is an increase in number of millable cane. Higher NMC was attributed to high tiller production, higher uptake and utilization of plant nutrients (Natarajan, 1998). The sulphur mediated nitrogen metabolism might have increased the nitrate reductase and sulphate reductase activities, thereby improving chlorophyll formation, which contributed greatly to increased number of millable canes and greater cane diameter (Jamal et al., 2003). The $\mathrm{T}_{3}(100 \% \mathrm{~N}+75 \% \mathrm{P} \& \mathrm{~K})$ and $\mathrm{T}_{4}(100 \% \mathrm{~N}+50 \%$ $\mathrm{P} \& \mathrm{~K})$ were on par with each other and recorded the minimum number of millable cane.

\section{Effect of balanced fertilization of sugarcane on nutrient content}

The effect of balanced fertilization on nutrient content of sugarcane was studied by analyzing the index leaf $\left(3-4^{\text {th }}\right.$ leaf) for leaf $N, P, K \& S$ content at different growth stages viz., $90^{\text {th }}$, 
$150^{\text {th }}, 210^{\text {th }}$, and $270^{\text {th }}$ days after planting (DAP) and at harvest indicated that declined with advancement of growth stages (Figure 25). With regards to nutrient content except on $90^{\text {th }}$ DAP in all other stages, the STCR based fertilizer application $\left(\mathrm{T}_{6}\right)$ on par with $\mathrm{T}_{5}$ $(125 \% \mathrm{~N}+75 \% \mathrm{P}+100 \% \mathrm{~K}), \mathrm{T}_{2}(125 \% \mathrm{~N}+$ $100 \% \mathrm{P} \& \mathrm{~K}), \mathrm{T}_{10}$ (TNAU package) or $\mathrm{T}_{9}$ (RSCL package) recorded the highest leaf $\mathrm{N}$ content of 2.40, 2.36, 2.34, 1.93 and $1.48 \%$ during $90^{\text {th }}, 150^{\text {th }}, 210^{\text {th }}, 270^{\text {th }}$ DAP and at harvest respectively. In general a gradual and steady decline in leaf $\mathrm{N}$ concentrations was recorded with advancement of growth stages. This might be due to dilution effect of $\mathrm{N}$ with growth period. Higher leaf $\mathrm{N}$ due to application of higher dose of nitrogen to sugarcane was also reported by Ibrahim (1979). The leaf $\mathrm{N}$ contents in all the treatments were within the sufficiency level upto $270^{\text {th }}$ DAP (Andersen and Bowen, 1990) who reported that a critical value for $\mathrm{N}$ as 1.8 $\%$ for sugarcane. Irrespective of the growth stages of sugarcane the lowest leaf $\mathrm{N}$ concentration of 2.10, 2.09, 2.07, 1.68 and $1.20 \%$ were recorded in $\mathrm{T}_{4}(100 \% \mathrm{~N}+50 \%$ $\mathrm{P} \& \mathrm{~K})$ which was on par with $\mathrm{T}_{1}$ (RDF) and $\mathrm{T}_{3}$ (100\% N+75\% P\&K). In the site all the five stages, the RSCL package $\left(\mathrm{T}_{9}\right)$ on par with $\mathrm{T}_{6}$ (STCR based fertilizer application), $\mathrm{T}_{8}\left(\mathrm{~T}_{7}+\mathrm{S}\right)$ and $\mathrm{T}_{7}\left(\mathrm{~T}_{1}+\mathrm{Zn}\right)$ recorded the highest leaf $\mathrm{P}$ content of $0.331,0.322,0.305,0.283$ and $0.264 \%$ during $90^{\text {th }}, 150^{\text {th }}, 210^{\text {th }}, 270^{\text {th }}$ DAP and at harvest respectively. The high $\mathrm{P}$ content in the plant tissues due to $\mathrm{P}$ nutrition enabled the plant to maintain high rate of metabolic and physiological activities, increase the sink size and utilize the photosynthate at a faster rate, which laid down the foundation of higher yield. This corroborates with the findings of Bokhtiar et al., (2002) and Kumar et al., (2004). The $\mathrm{T}_{4}(100 \% \mathrm{~N}+50 \% \mathrm{P} \& \mathrm{~K})$ recorded the minimum leaf $\mathrm{P}$ content of $0.212,0.204$, $0.185,0.166$ and $0.147 \%$ at different growth stages of sugarcane. In the RSCL farm the TNAU package $\left(T_{10}\right)$ recorded the highest leaf
K content of 2.64, 2.56, 2.27, 1.92 and $1.53 \%$ during $90^{\text {th }}, 150^{\text {th }}, 210^{\text {th }}, 270^{\text {th }}$ DAP and at harvest respectively. The results showed that the higher level of K application @ $200 \mathrm{~kg}$ $\mathrm{K}_{2} \mathrm{O}$ ha $^{-1}$ increased the $\mathrm{K}$ concentration in index leaf which enhanced the activities of leaf carbonic anhydrase (CA) and nitrate reductase (NR) thereby inducing efficient photosynthesis and the formation of primary organic N-containing molecules necessary for amino acids required for protein synthesis. The increasing level of $K$ increased the activities of photosynthesis, protein synthesis and regulation of stomatal movement (Marschner, 1995). In general, $\mathrm{T}_{4}(100 \%$ $\mathrm{N}+50 \% \mathrm{P} \& \mathrm{~K})$ recorded the lowest $\mathrm{K}$ content while $\mathrm{T}_{10}$ (TNAU package) recorded the highest $\mathrm{K}$ content. In general a gradual and steady decline in $\mathrm{K}$ concentrations of the leaves was noted with advancing crop growth stages. Sangwan et al., (2010) also reported that the application of $\mathrm{K}$ fertilizers upto 125 $\mathrm{kg} \mathrm{K}_{2} \mathrm{O} \mathrm{ha}^{-1}$ increased the $\mathrm{K}$ concentration in index leaf of sugarcane. Irrespective of the growth stages of sugarcane the lowest leaf $\mathrm{K}$ content of 1.81, 1.83, 1.62, 1.30 and $1.17 \%$ was recorded in $\mathrm{T}_{4}(100 \% \mathrm{~N}+50 \% \mathrm{P} \& \mathrm{~K})$.

Sulphur is a key component of balanced nutrient application for yields and superior quality of the produce. In the site except $90^{\text {th }}$ and $150^{\text {th }} \mathrm{DAP}$ in remaining growth stages, the RSCL package $\left(\mathrm{T}_{9}\right)$ on par with $\mathrm{T}_{8}\left(\mathrm{~T}_{7}+\mathrm{S}\right)$ recorded the highest leaf $\mathrm{S}$ content of 0.280 , $0.251,0.226,0.185$ and $0.148 \%$ during $90^{\text {th }}$, $150^{\text {th }}, 210^{\text {th }}, 270^{\text {th }}$ DAP and at harvest respectively. In general, a gradual and steady decline in S concentrations of the leaves was noted with progressing crop growth stages. Bokhtiar and Sakurai (2004) also observed that the $\mathrm{S}$ content was higher at tillering stage than grand growth stage and further decreased with advancement of crop growth. Joshi and Amodkar (2000) also reported that application of $60 \mathrm{~kg} \mathrm{~S} \mathrm{ha}^{-1}$ increased the $\mathrm{S}$ content in leaves from 0.188 to $0.238 \%$. 
Fig.1 Study area of Theni district of Tamil Nadu

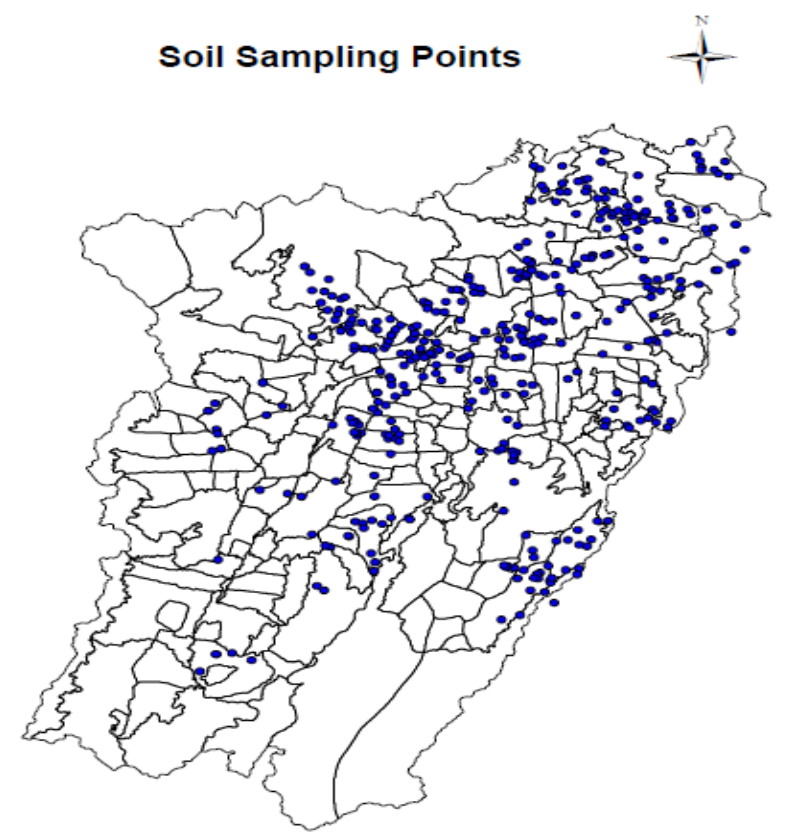

Table.1 Treatment details and fertilizer application

\begin{tabular}{|c|c|}
\hline $\mathbf{T}_{1}-$ & Recommended dose of fertilizers $\mathrm{N}, \mathrm{P}_{2} \mathrm{O}_{5}, \mathrm{~K}_{2} \mathrm{O} @ 275: 150: 150 \mathrm{~kg} \mathrm{ha}^{-1}$ \\
\hline $\mathbf{T}_{2}-$ & $125 \% \mathrm{~N}+100 \% \mathrm{P}_{2} \mathrm{O}_{5}+100 \% \mathrm{~K}_{2} \mathrm{O}$ \\
\hline $\mathbf{T}_{\mathbf{3}}-$ & $100 \% \mathrm{~N}+75 \% \mathrm{P}_{2} \mathrm{O}_{5}+75 \% \mathrm{~K}_{2} \mathrm{O}$ \\
\hline $\mathbf{T}_{4}-$ & $100 \% \mathrm{~N}+50 \% \mathrm{P}_{2} \mathrm{O}_{5}+50 \% \mathrm{~K}_{2} \mathrm{O}$ \\
\hline $\mathbf{T}_{5}-$ & $125 \% \mathrm{~N}+75 \% \mathrm{P}_{2} \mathrm{O}_{5}+100 \% \mathrm{~K}_{2} \mathrm{O}$ \\
\hline $\mathbf{T}_{6}-$ & STCR based fertilizer prescription for an yield target of $150 \mathrm{t} \mathrm{ha}^{-1} *$ \\
\hline $\mathbf{T}_{7}-$ & $\mathrm{T}_{1}+\mathrm{Zn}\left(\right.$ as $\left.\mathrm{ZnSO}_{4}\right) @ 25 \mathrm{~kg} \mathrm{ha}^{-1}$ \\
\hline $\mathbf{T}_{8}-$ & $\mathrm{T}_{7}+$ elemental S (as Gromor) @ $25 \mathrm{~kg} \mathrm{ha}^{-1}$ \\
\hline $\mathbf{T}_{9}-$ & $\begin{array}{l}\text { RSCL package T1+ elemental S (as Gromor) and } \mathrm{ZnSO}_{4} \text { each @ } 25 \mathrm{~kg} \mathrm{ha}^{-1}, \mathrm{FeSO}_{4} \\
\text { @ } 50 \mathrm{~kg} \mathrm{ha}^{-1} \text { and Bio-A (Azospirillum), } \mathrm{P} \text { (Bacillus subtilis ) and } \mathrm{K} \text { (Frateuria) each } \\
\text { @ } 2.5 \mathrm{~L} \mathrm{ha}^{-1}\end{array}$ \\
\hline $\mathbf{T}_{10}-$ & $\begin{array}{l}\text { TNAU package (300:100:200:100:37.5 for } \mathrm{N}, \mathrm{P}_{2} \mathrm{O}_{5}, \mathrm{~K}_{2} \mathrm{O}, \mathrm{FeSO}_{4}, \mathrm{ZnSO}_{4} \mathrm{~kg} \mathrm{ha}^{-1} \text { and } \\
\text { Azospirillum and phosphate solubilizing bacteria each @ } 2 \mathrm{~kg} \mathrm{ha}^{-1} \text { ) }\end{array}$ \\
\hline
\end{tabular}

*STCR based fertilizer prescription was computed based on the following equation is given below.

$\mathrm{FN}=3.42(200)-0.56(226)-0.93(1.8)=555.4 \mathrm{~kg} \mathrm{ha}^{-1}$

$\mathrm{FP}_{2} \mathrm{O}_{5}=1.15(200)-1.94(43)-0.98(1.2)=145.4 \mathrm{~kg} \mathrm{ha}^{-1}$

$\mathrm{F} \mathrm{K}_{2} \mathrm{O}=3.16(200)-0.73(705)-0.99(3.5)=114.6 \mathrm{~kg} \mathrm{ha}^{-1}$ 
Table.2 Range of physico-chemical and nutrients status of sugarcane growing areas of Theni district

\begin{tabular}{|c|c|c|c|c|c|c|c|c|c|c|}
\hline \multirow[t]{2}{*}{ Division } & \multirow[t]{2}{*}{ pH } & \multirow{2}{*}{$\begin{array}{c}\mathrm{EC} \\
\left(\mathrm{dSm}^{-1}\right)\end{array}$} & \multirow{2}{*}{$\begin{array}{c}\text { Org. } \\
\text { carbon } \\
\left(\mathrm{g} \mathrm{kg}^{-1}\right)\end{array}$} & Av. $\mathbf{N}$ & Av. $P$ & Av. $K$ & $\mathbf{F e}$ & Mn & Zn & $\mathrm{Cu}$ \\
\hline & & & & \multicolumn{3}{|c|}{$\left(\mathrm{kg} \mathrm{ha}^{-1}\right)$} & \multicolumn{4}{|c|}{$\left(\mathrm{mg} \mathrm{kg}^{-1}\right)$} \\
\hline Jeyamangalam & $\begin{array}{c}6.32- \\
8.65 \\
(7.72)\end{array}$ & $\begin{array}{c}0.05- \\
0.93 \\
(0.27)\end{array}$ & $\begin{array}{c}1.3-13.5 \\
(6.6)\end{array}$ & $\begin{array}{c}154-326 \\
(224)\end{array}$ & $\begin{array}{c}20-283 \\
(55)\end{array}$ & $\begin{array}{l}130- \\
1518 \\
(596)\end{array}$ & $\begin{array}{c}2.0- \\
82.4 \\
(12.1)\end{array}$ & $\begin{array}{c}2.1- \\
18.4 \\
(5.60)\end{array}$ & $\begin{array}{c}0.4-9.9 \\
(1.90)\end{array}$ & $\begin{array}{l}1.0- \\
11.1 \\
(3.40)\end{array}$ \\
\hline Periyakulam & $\begin{array}{c}6.13- \\
8.45 \\
(7.80)\end{array}$ & $\begin{array}{c}0.07- \\
0.94 \\
(0.26)\end{array}$ & $\begin{array}{c}0.9-12.1 \\
(5.7)\end{array}$ & $\begin{array}{c}88-260 \\
(200)\end{array}$ & $\begin{array}{c}9-157 \\
(45)\end{array}$ & $\begin{array}{c}93-1501 \\
(354)\end{array}$ & $\begin{array}{c}2.5- \\
91.9 \\
(18.8)\end{array}$ & $\begin{array}{c}1.0- \\
21.4 \\
(5.10)\end{array}$ & $\begin{array}{c}0.3-9.7 \\
(1.63)\end{array}$ & $\begin{array}{c}1.3-4.8 \\
(2.91)\end{array}$ \\
\hline Theni & $\begin{array}{c}6.78- \\
8.46 \\
(7.79) \\
\end{array}$ & $\begin{array}{c}0.10- \\
0.64 \\
(0.26) \\
\end{array}$ & $\begin{array}{c}1.3-14.6 \\
(5.9)\end{array}$ & $\begin{array}{c}138-367 \\
(213)\end{array}$ & $\begin{array}{c}31-135 \\
(69)\end{array}$ & $\begin{array}{l}140- \\
1820 \\
(564)\end{array}$ & $\begin{array}{l}1.4- \\
18.1 \\
(6.72 \\
\end{array}$ & $\begin{array}{c}1.2- \\
18.2 \\
(3.73)\end{array}$ & $\begin{array}{c}0.2-3.4 \\
(0.94)\end{array}$ & $\begin{array}{c}0.9-7.8 \\
(2.14)\end{array}$ \\
\hline P.C. Patti & $\begin{array}{c}5.97- \\
9.11 \\
(8.01)\end{array}$ & $\begin{array}{c}0.08- \\
0.83 \\
(0.29)\end{array}$ & $\begin{array}{c}0.7-13.6 \\
\quad(5.6)\end{array}$ & $\begin{array}{c}119-279 \\
(211)\end{array}$ & $\begin{array}{c}23-142 \\
(72)\end{array}$ & $\begin{array}{c}85-2010 \\
(636)\end{array}$ & $\begin{array}{c}1.8- \\
128.6 \\
(12.63)\end{array}$ & $\begin{array}{c}2.1- \\
17.1 \\
(7.01)\end{array}$ & $\begin{array}{c}0.1-7.7 \\
(1.38)\end{array}$ & $\begin{array}{c}0.8-8.2 \\
(2.56)\end{array}$ \\
\hline Cumbum & $\begin{array}{c}4.70- \\
8.60 \\
(7.46)\end{array}$ & $\begin{array}{c}0.04- \\
1.25 \\
(0.20)\end{array}$ & $\begin{array}{c}0.6-13.9 \\
(5.5)\end{array}$ & $\begin{array}{c}113-448 \\
(225)\end{array}$ & $\begin{array}{c}9-131 \\
(51)\end{array}$ & $\begin{array}{l}152- \\
1696 \\
(523)\end{array}$ & $\begin{array}{c}3.3- \\
128.9 \\
(21.3)\end{array}$ & $\begin{array}{c}2.1- \\
37.3 \\
(13.4)\end{array}$ & $\begin{array}{l}0.2- \\
12.8 \\
(2.40)\end{array}$ & $\begin{array}{c}0.8-7.3 \\
(2.49)\end{array}$ \\
\hline Bodi & $\begin{array}{l}5.30- \\
8.91 \\
(8.0)\end{array}$ & $\begin{array}{c}0.04- \\
0.90 \\
(0.23)\end{array}$ & $\begin{array}{c}0.4-12.4 \\
\quad(5.1)\end{array}$ & $\begin{array}{c}69-301 \\
(187)\end{array}$ & $\begin{array}{c}24-135 \\
(58)\end{array}$ & $\begin{array}{c}83-1613 \\
(440)\end{array}$ & $\begin{array}{c}1.8- \\
84.6 \\
(12.34)\end{array}$ & $\begin{array}{c}2.4- \\
38.5 \\
(7.37)\end{array}$ & $\begin{array}{c}0.2-8.3 \\
(1.44)\end{array}$ & $\begin{array}{c}0.7-5.5 \\
(2.46)\end{array}$ \\
\hline Andipatti & $\begin{array}{c}6.99- \\
9.20 \\
(8.19)\end{array}$ & $\begin{array}{c}0.03- \\
1.64 \\
(0.31)\end{array}$ & $\begin{array}{c}0.4-11.6 \\
(5.0)\end{array}$ & $\begin{array}{c}97-320 \\
(202)\end{array}$ & $\begin{array}{c}11-142 \\
(50)\end{array}$ & $\begin{array}{l}130- \\
1098 \\
(536)\end{array}$ & $\begin{array}{c}2.0- \\
138.0 \\
(12.12)\end{array}$ & $\begin{array}{c}2.4- \\
45.1 \\
(11.16)\end{array}$ & $\begin{array}{c}0.2-5.3 \\
(1.41)\end{array}$ & $\begin{array}{c}0.5-3.9 \\
(1.80)\end{array}$ \\
\hline Mailadumparai & $\begin{array}{c}7.32- \\
9.12 \\
(8.39)\end{array}$ & $\begin{array}{c}0.07- \\
0.89 \\
(0.25) \\
\end{array}$ & $\begin{array}{c}1.2-12.8 \\
(5.8)\end{array}$ & $\begin{array}{c}91-263 \\
(197)\end{array}$ & $\begin{array}{c}11-90 \\
(42)\end{array}$ & $\begin{array}{c}94-1714 \\
(460)\end{array}$ & $\begin{array}{c}2.2- \\
72.1 \\
(7.51)\end{array}$ & $\begin{array}{c}2.2- \\
18.7 \\
(8.73)\end{array}$ & $\begin{array}{c}0.2-6.7 \\
(1.67)\end{array}$ & $\begin{array}{c}0.6-2.9 \\
(1.70)\end{array}$ \\
\hline
\end{tabular}


Table.3 Correlation between soil physico-chemical properties and available nutrients of soils

\begin{tabular}{|c|c|c|c|c|c|c|c|c|c|c|c|c|}
\hline & pH & EC & OC & Av. $\mathbf{N}$ & Av. $P$ & Av. K & $\mathrm{CaC}$ & Av. S & Av. Fe & Av. Mn & Av. Zn & Av. $\mathrm{Cu}$ \\
\hline pH & 1.0 & 0.12 & - & -0.172 & -0.024 & 0.154 & 0.336 & 0.035 & - & $-0.443^{*}$ & $-0.305^{*}$ & $-0.302 *$ \\
\hline EC & & 1.00 & 0.204 & 0.103 & 0.097 & 0.298 & 0.031 & $0.561 * *$ & -0.172 & -0.025 & -0.001 & 0.049 \\
\hline OC & & & 1.00 & $0.399 * *$ & 0.238 & 0.220 & -0.016 & $0.207^{*}$ & 0.148 & 0.051 & $0.277 *$ & $0.367 *$ \\
\hline Av. $\mathbf{N}$ & & & & 1.00 & 0.165 & 0.249 & 0.007 & 0.059 & 0.050 & 0.002 & 0.061 & $0.328 *$ \\
\hline Av. P & & & & & 1.00 & 0.197 & -0.123 & 0.040 & $-0.270 *$ & -0.082 & $-0.235^{*}$ & 0.110 \\
\hline Av. $K$ & & & & & & 1.00 & 0.069 & $0.276^{*}$ & -0.184 & -0.086 & 0.018 & 0.025 \\
\hline $\mathrm{CaCO}$ & & & & & & & 1.00 & 0.007 & -0.151 & -0.102 & -0.070 & -0.173 \\
\hline Av. S & & & & & & & & 1.00 & -0.035 & 0.014 & 0.024 & -0.011 \\
\hline Av. Fe & & & & & & & & & 1.00 & $0.357 * * *$ & $0.438 * *$ & $0.290^{*}$ \\
\hline Av. & & & & & & & & & & 1.00 & 0.18029 & -0.049 \\
\hline Av. & & & & & & & & & & & 1.00 & 0.186 \\
\hline Av. & & & & & & & & & & & & 1.00 \\
\hline
\end{tabular}

Fig.2 Nitrogen content (\%) in leaf tissues of sugarcane in different growth stages

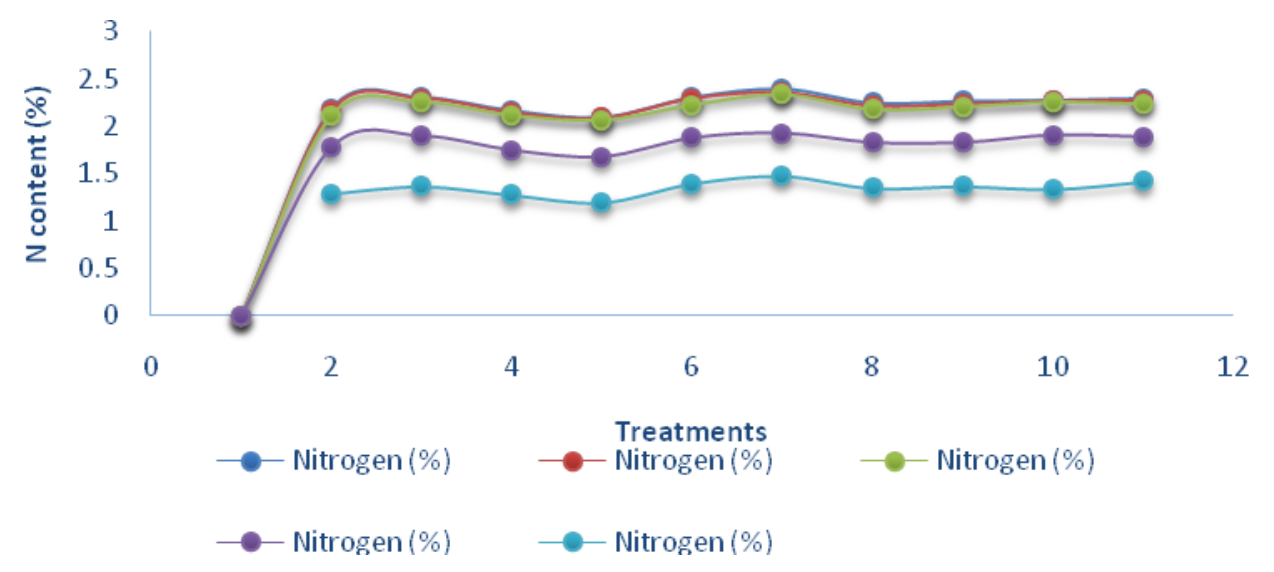


Table.4 Effect of balanced fertilization on yield attributes, juice quality and B:C ratio of sugarcane at RSCL farm

\begin{tabular}{|c|c|c|c|c|c|c|c|}
\hline $\begin{array}{c}\text { Treatme } \\
\text { nt No. }\end{array}$ & $\begin{array}{l}\text { No. of tillers } \\
\left(\times 10^{3} \mathrm{ha}^{-1}\right)\end{array}$ & $\begin{array}{l}\text { Number of } \\
\text { millable cane } \\
\left(\times 10^{3} \mathrm{ha}^{-1}\right)\end{array}$ & $\begin{array}{c}\text { Brix } \\
(\%)\end{array}$ & $\begin{array}{l}\text { Pol } \\
(\%)\end{array}$ & $\begin{array}{l}\text { Purity } \\
(\%)\end{array}$ & $\begin{array}{l}\text { CCS } \\
(\%)\end{array}$ & $\begin{array}{l}\text { B:C } \\
\text { ratio }\end{array}$ \\
\hline $\mathbf{T}_{1}$ & 166.2 & 104.6 & 20.93 & 18.44 & 88.19 & 12.74 & 2.39 \\
\hline $\mathbf{T}_{2}$ & 181.9 & 119.4 & 21.05 & 18.66 & 88.65 & 12.92 & 2.43 \\
\hline $\mathbf{T}_{3}$ & 162.0 & 102.8 & 20.34 & 17.97 & 88.47 & 12.43 & 2.40 \\
\hline $\mathbf{T}_{4}$ & 158.3 & 99.1 & 19.93 & 17.73 & 88.96 & 12.30 & 2.38 \\
\hline $\mathbf{T}_{5}$ & 175.9 & 112.0 & 20.90 & 18.50 & 88.50 & 12.80 & 2.40 \\
\hline $\mathbf{T}_{6}$ & 184.7 & 122.7 & 21.15 & 19.06 & 90.14 & 13.31 & 2.37 \\
\hline $\mathbf{T}_{7}$ & 171.8 & 108.3 & 20.69 & 18.55 & 89.70 & 12.92 & 2.40 \\
\hline $\mathbf{T}_{8}$ & 175.0 & 110.6 & 20.85 & 18.56 & 89.09 & 12.88 & 2.39 \\
\hline $\mathbf{T}_{9}$ & 183.3 & 120.4 & 21.52 & 19.47 & 90.78 & 13.62 & 2.45 \\
\hline $\mathbf{T}_{10}$ & 179.6 & 115.7 & 21.09 & 18.83 & 89.31 & 13.09 & 2.43 \\
\hline SEd & 3.36 & 3.05 & 0.551 & 0.447 & \multirow[t]{2}{*}{ NS } & 0.450 & \\
\hline $\begin{array}{c}\text { CD } \\
(P=0.05)\end{array}$ & 7.05 & 6.40 & 1.158 & 0.938 & & 0.946 & \\
\hline
\end{tabular}

Fig.3 Phosphorus content (\%) in leaf tissues of sugarcane in different growth stages

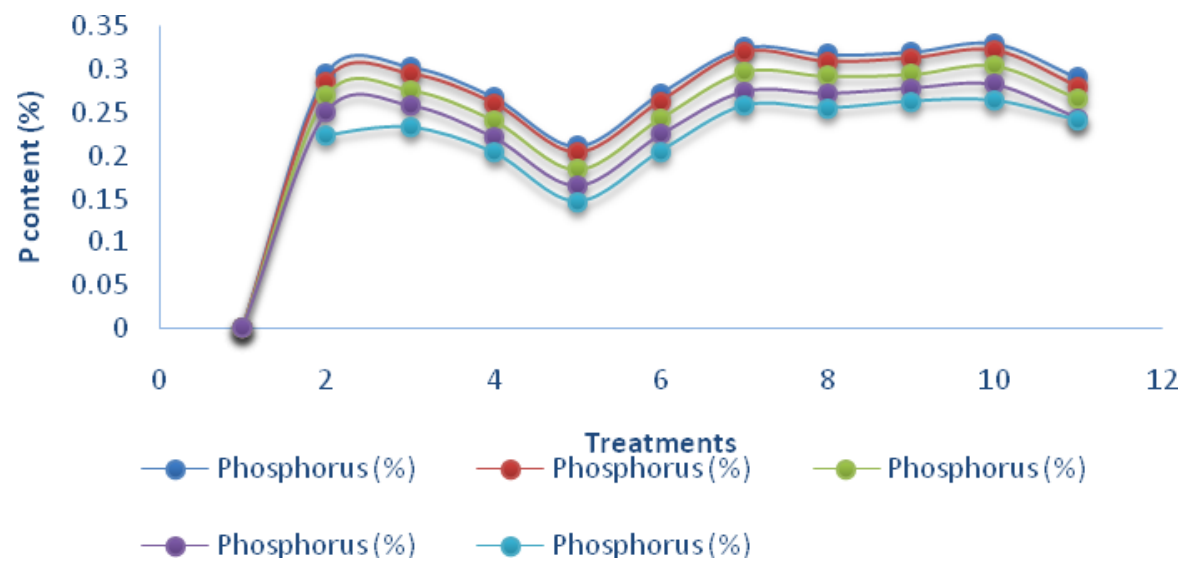


Fig.4 Potassium content (\%) in leaf tissues of sugarcane in different growth stages

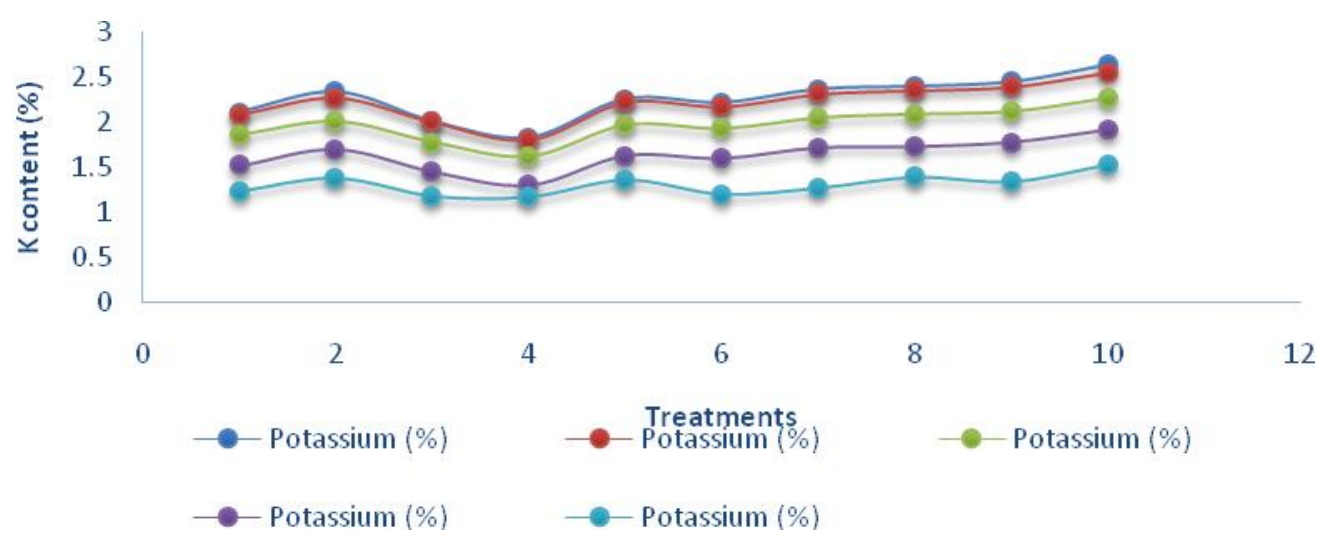

Fig.5 Sulphur content (\%) in leaf tissues of sugarcane in different growth stages

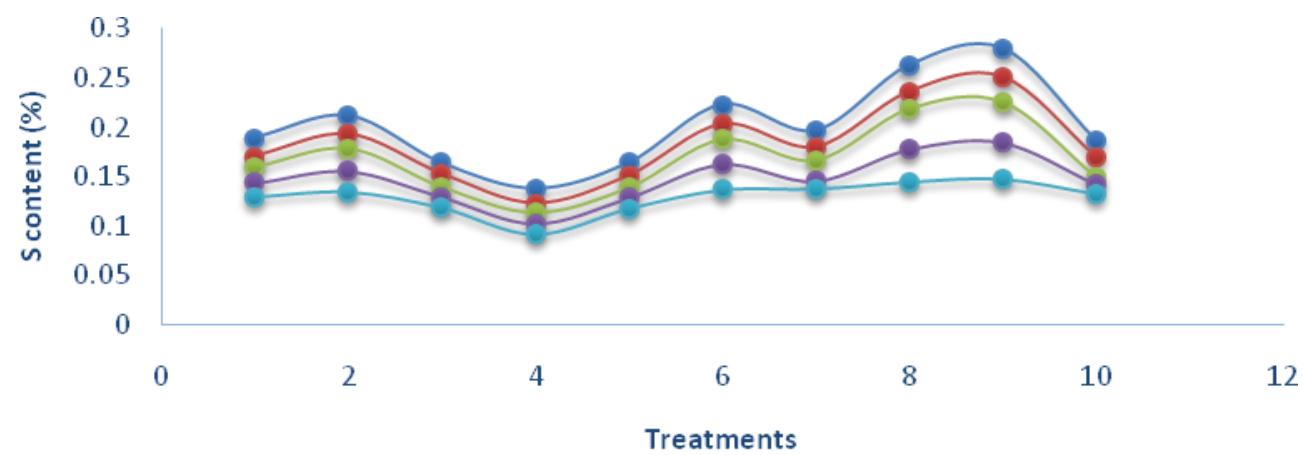

$\longrightarrow$ Sulphur $(\%) \longrightarrow$ Sulphur $(\%)-$ Sulphur $(\%) \rightarrow-$ Sulphur $(\%)-$ Sulphur $(\%)$

Fig.6 Effect of balanced fertilization on cane yield ( $\mathrm{t} \mathrm{ha}^{-1}$ ) at RSCL farm

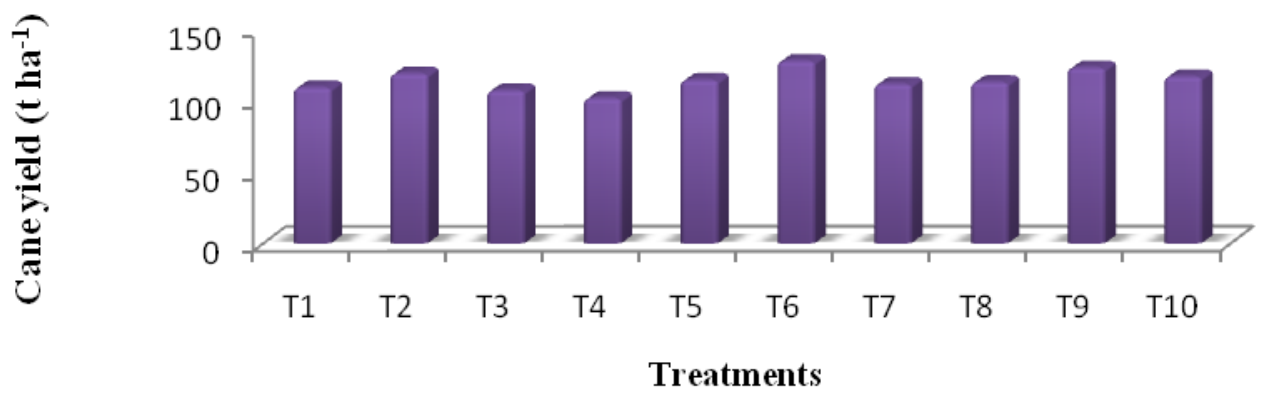


Fig.7 Effect of balanced fertilizationon sugar yield $\left(\mathrm{t} \mathrm{ha}^{-1}\right)$ at RSCL farm

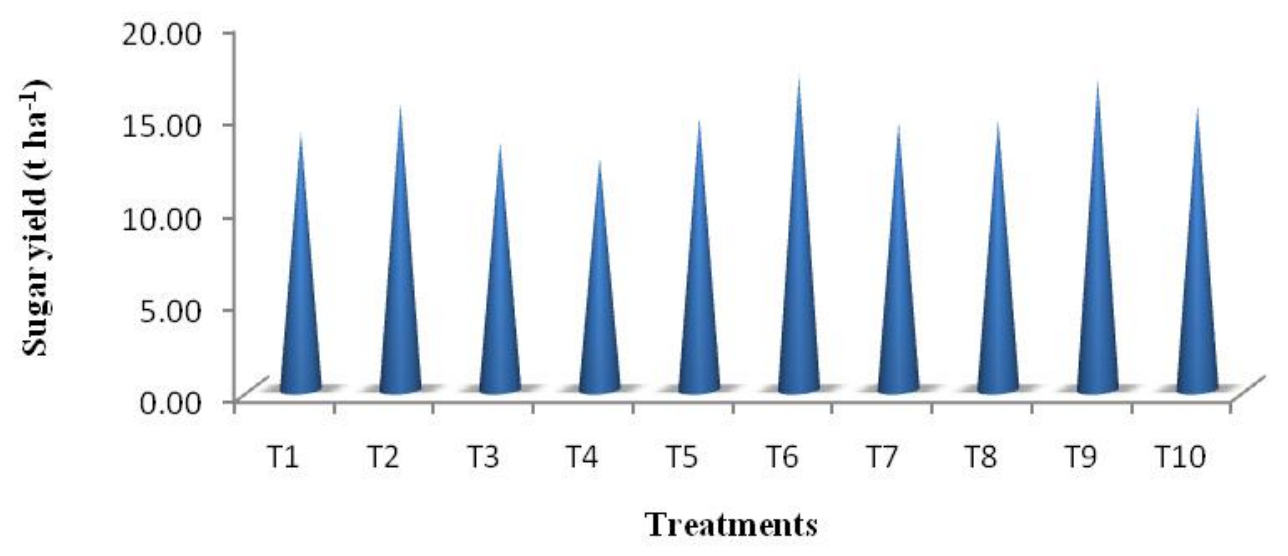

The figures represent $\mathrm{CD} 0.05$ values

Irrespective of the growth stages of sugarcane the lowest leaf $\mathrm{S}$ content of $0.138,0.123$, $0.114,0.103$ and $0.092 \%$ was recorded in $\mathrm{T}_{4}$ (100\% N+50\% P\&K).

\section{Effect of balanced fertilization on quality parameters of sugarcane}

Quality of the crops is very important in deciding the economic value of the produce. In sugarcane, brix \%, sucrose $\%$ and CCS $\%$ are the deciding factors for quality assessment (Table 3). Hence, it is essential to study the effect of balanced fertilization on the quality of the produce for deciding the value of the produce. The effect of balanced fertilization on brix, pol and CCS \% of sugarcane juice varied from 19.93 to $21.52,17.73$ to 19.47 and 12.30 to $13.62 \%$ respectively. Among the treatments, the RSCL package $\left(\mathrm{T}_{9}\right)$ recorded the highest brix, pol and CCS \% of 21.52, 19.47 and 13.62. The increase in quality attributes in the form of brix, pol and CCS \% might be due to the balanced supply of nutrients through inorganic fertilizers along with bio-compost and bio-fertilizers, enhanced plants physiological activities which had improved the juice quality of cane. Thangavelu (2007) recorded significantly higher brix and pol \% juice of cane grown with $\mathrm{Zn}$ fertilization in addition to NPK as compared to those without fertilizers or supplied only with NPK. Singh et al., (1997) also observed a significant increase in brix \% in sugarcane due to application of $\mathrm{Zn}$. Compared to RSCL package the STCR based fertilizer application recorded lower quality parameters which might be due to higher dose of $\mathrm{N}$ addition resulting in vigorous crop growth leading to increased diversion of photosynthate and minerals to meet the requirements for vegetative growth. Also, utilization of photosynthate for sucrose accumulation might have been reduced, resulting in lower brix reported by Rakkiyappan (1987). As in the case of sucrose $\%$, the CCS \% was also affected by the increased doses of applied $\mathrm{N}$ and the reduction in CCS \% was probably due to the reduced sucrose $\%$.

\section{Effect of balanced fertilization of sugarcane yield and economics at RSCL farm}

\section{Cane yield}

The effect of balanced fertilization on sugarcane yield was found to be significant is 
given in Fig. 6. The mean value of sugarcane yield varied from 101.9 to $128 \mathrm{t} \mathrm{ha}^{-1}$. Among the treatment practiced, the STCR based fertilizers application $\left(\mathrm{T}_{6}\right)$ recorded the highest cane yield of 128 which was on par with $\mathrm{T}_{9}$ (RSCL package). Increase in cane yield with phosphorus supply might be attributed to increase in number of millable canes at harvest. As soil $\mathrm{pH}, \mathrm{P}$ and $\mathrm{Mn}$ concentrations were important factors in predicting sugarcane yield (Kaler et al., 2017).It was confirmed that a significant positive correlation was observed between number of millable cane and cane yield $(\mathrm{r}=0.798 * *)$ at harvest stage (Arjun et al., 2008).Compared to the existing $\operatorname{RDF}\left(\mathrm{T}_{1}\right)$, $\mathrm{T}_{6}$ and $\mathrm{T}_{9}$ recorded 16.9 and $12.6 \%$ increase in sugarcane yield indicated that the balanced use of inorganic fertilizers, bio-compost and biofertilizers resulted in higher productivity. This balanced fertilization mainly attributed to the increase of metabolic process resulting in building up of dry matter in sugarcane, improvement in soil fertility and increase in total yield due to study nutrient supply (Bakiyathu Saliha, 2009). Choudhary and Sinha (2001) also reported that positive improvement in all the growth and yield attributes by balanced dose of fertilization that led to accelerated carbohydrates production and utilization which ultimately resulted in higher yield.

Also $\mathrm{T}_{2}(125 \% \mathrm{~N}+100 \% \mathrm{P} \& \mathrm{~K})$ on par with $\mathrm{T}_{9}$ and $\mathrm{T}_{10}$ (TNAU package) established the nonnecessity for excess $\mathrm{N}$ application above the $100 \%$ recommended dose of fertilizers. The results proved the advantages of balanced fertilization on cane yield; it implies that there are no deficiencies, no excess, no antagonisms and no negative interactions.

The cane yield in $\mathrm{T}_{9}$ (RSCL package) was significantly increased due to the application of $\mathrm{ZnSO}_{4}\left(25 \mathrm{~kg} \mathrm{ha}^{-1}\right), \mathrm{FeSO}_{4}\left(50 \mathrm{~kg} \mathrm{ha}^{-1}\right)$ and elemental S $\left(25 \mathrm{~kg} \mathrm{ha}^{-1}\right)$. Organic resources are not only sources of major nutrients, but also provide several micronutrients and plant growth promoting hormones, which get together leading to better crop yields reported by Tyagiet al., (2011). Increase in cane yield with sulphur application was reported by Aneg Singh et al., (2003). The higher cane yield with Zn application@ @ $25 \mathrm{~kg} \mathrm{ZnSO}_{4} \mathrm{ha}^{-1}$ might be due to the favourable effects of $\mathrm{Zn}$ on the biosynthesis of plant hormone, IAA, which in turn increased the plant height, number of internodes and millable canes as reported by Rohtash Kumar and Singh (1997). As $\mathrm{T}_{8}\left(\mathrm{~T}_{7}+\mathrm{S}\right)$ and $\mathrm{T}_{7}\left(\mathrm{~T}_{1}+\mathrm{Zn}\right)$ on par with RDF $\left(\mathrm{T}_{1}\right)$ there is no response to separate application of either $\mathrm{ZnSO}_{4} @ 25 \mathrm{~kg} \mathrm{ha}^{-1}$ or sulphur@ $25 \mathrm{~kg} \mathrm{ha}^{-1}$ alone or in combination was not established. As $\mathrm{T}_{3}(100 \% \mathrm{~N}+75 \%$ $\mathrm{P} \& \mathrm{~K})$ and $\mathrm{T}_{5}(125 \% \mathrm{~N}+75 \% \mathrm{P}+100 \% \mathrm{~K})$ on par with $\mathrm{T}_{1}(\mathrm{RDF})$ about $25 \% \mathrm{P}$ can be reduced.

As soil contain high in native $\mathrm{P}$ and $\mathrm{K}$ the use of $\mathrm{P}$ and $\mathrm{K}$ solubilizing bacteria is efficient to utilize fixed nutrients. On the other hand reducing $\mathrm{P}$ and $\mathrm{K}$ to the tune of $50 \%$ in $\mathrm{T}_{4}$ resulted significantly lower cane yield; hence $\mathrm{P}$ and $\mathrm{K}$ doses can not be reduced to beyond $25 \%$.

This might be due to imbalanced application of fertilizers results in poor yields, deterioration of soil fertility and emergence of multiple nutrient deficiencies as reported by Tyagi et al., (2011) (Table 4).

\section{Sugar yield}

The effect of balanced fertilization on sugar yield was found to be significant is given in Fig. 7. The mean sugar yield varied between 12.54 and $17.04 \mathrm{t} \mathrm{ha}^{-1}$. The STCR based fertilizer application $\left(\mathrm{T}_{6}\right)$ recorded the highest sugar yield of $17.04 \mathrm{t} \mathrm{ha}^{-1}$ which was on par with the RSCL package $\left(T_{9}\right)$ at RSCL farm $\left(16.78 \mathrm{t} \mathrm{ha}^{-1}\right)$. Sugar yield had similar trend as 
that of the cane yield indicating that the juice quality did not influence the sugar yield significantly. The results are in agreement with the earlier findings of Shukla and Lal (2007) followed by Sreelatha et al., (2010) who reported that though juice quality is more in organic manure treatments and sugar yield is significantly less due to less cane yields. An, application of $100 \% \mathrm{~N}$ and $50 \% \mathrm{P}$ and $\mathrm{K}$ of RDF $\left(\mathrm{T}_{4}\right)$ recorded the lowest sugar yield of $12.54 \mathrm{t} \mathrm{ha}^{-1}$.

\section{Benefit: Cost ratio}

The details of cost of cultivation, gross income, net income and Benefit: Cost ratios of sugarcane in the experimental site given in Table 3. The total cost of cultivation of sugarcane varied from Rs. 100,312 to 126,314 $\mathrm{ha}^{-1}$ among the different treatment. The net income, among the treatment varied from Rs. 138,134 to $173,440 \mathrm{ha}^{-1}$ at the sites. The overall, RSCL package $\left(\mathrm{T}_{9}\right)$ and TNAU package $\left(\mathrm{T}_{10}\right)$ recorded the highest $\mathrm{B}$ : $\mathrm{C}$ ratio of 2.45 and 2.43 respectively at RSCL farm. The higher cost of cultivation and gross and net return was noticed with STCR based fertilizer application $\left(\mathrm{T}_{6}\right)$, which might be due to application of higher dose of nitrogenous fertilizers based on targeted yield approach.

It can be concluded that the soils of the Theni district as assessed in the major blocks are acidic to alkaline in reaction. Invariably all the soil samples collected from the 8 divisions of sugarcane growing area recorded EC of less than $2 \mathrm{dSm}^{-1}$ indicating that the soils are free from salinity. Low available nitrogen status (< $280 \mathrm{~kg} \mathrm{ha}^{-1}$ ) indicates that nitrogen is the major limiting nutrient in the soils. The soil samples were high in available phosphorus $(>22 \mathrm{~kg}$ $\left.\mathrm{ha}^{-1}\right)$ and high in available potassium $(>280 \mathrm{~kg}$ $\mathrm{ha}^{-1}$ ) status. More than 50 per cent of the soil samples were deficient in available zinc from all the sugarcane growing divisions. The georeferenced sampling sites can be revisited with the help of GPS, which helps in monitoring the changes in the status of nutrients over a period of time, which otherwise is not possible by traditional methods of sampling. Studies on $\mathrm{FeSO}_{4}$ requirement of sugarcane may be taken up as there was response to $\mathrm{FeSO}_{4}$ application @ $50 \mathrm{~kg} \mathrm{ha}^{-1}\left(\mathrm{~T}_{9}\right)$ and @ $100 \mathrm{~kg} \mathrm{ha}^{-1}\left(\mathrm{~T}_{10}\right)$. The recommendation of sulphur @ $25 \mathrm{~kg} \mathrm{ha}^{-1}$ and $\mathrm{ZnSO}_{4} @ 25 \mathrm{~kg} \mathrm{ha}^{-1}$ may be specifically made to deficient areas as there was no response in an experimental site. Though, the factory average sugarcane yield could be increased upto $128 \mathrm{t} \mathrm{ha}^{-1}$, increasing it beyond that needs attention on the following. Based upon the experimental results, a treatment combination of 275 to $300 \mathrm{~kg} \mathrm{~N}, 112.5 \mathrm{~kg}$ $\mathrm{P}_{2} \mathrm{O}_{5}, 150 \mathrm{~kg} \mathrm{~K} \mathrm{~K}_{2} \mathrm{O}$ and $50 \mathrm{~kg} \mathrm{FeSO}_{4}$ per ha along with input like bio-compost and biofertilizers can be validated through a farm trials in farmers' fields to increase the sugarcane yield beyond $128 \mathrm{t} \mathrm{ha}^{-1}$.

\section{References}

Achuthan, M., Charimakkani, A. and Rajasekaran, S. (1989). Studies on the effect of different levels of nitrogen and time of application on yield and quality of early maturing sugarcane varieties. Bharatiya Sugar, 14(4): 61-68.

Anderson, D.L. and Bowen, J.E. (1990). Sugarcane nutrition. Norcross, GA: Potash and Phosphate Institute.

Aneg Singh, Srivastava, R.N. and Singh, S.B. (2003). Effect of nutrient combinations on sugarcane productivity. Sugar Technology, 5(4): 311-313.

Anonymous. (2005) Agri. Situation in India, agristat. http//www.des.kar.nic.in.

Arjun, P., Ishwar, S. and Kamta P. (2008). Compatibility of zinc application with sources and levels of phosphorus in sugarcane (Saccharum spp hybrid). Indian Journal Sugarcane Technology, 23(1\&2): 22-25.

BakiyathuSaliha, B., Balaji, T. and James Pitchai, G. (2009). Evaluation of fertilizer optima for improving the quality of cane in Palaviduthi soil series of Tamil Nadu. 
Sugar Journal-40 ${ }^{\text {th }}$ Annual Convention of SISSTA, 43-47.

Balaji, T., Mani, S., Saravanan, A. and Nagaendra Rao, T. (2006). Balanced fertilization for maximizing the yield of sugarcane in Periyar Vaigai Command area. Indian Sugar, 56(5): 43-50.

Bhander, P.K., Bhuiya, M.S.U. and Salam, M.A. (1998). Effect of Sesbaniarostratabiomass and nitrogen fertilizer on the yield and yield attributes of transplant Amam rice. Progressive Agriculture, 9: 89-93.

Bokhtiar, S.M., Alam, M.J., Mohmood, K. and Rahman, M.H. (2002). Integrated nutrient management on productivity and economics of sugarcane under three agroecological zones of Bangladesh. Pakistan Journal of Biological Science, 5(4): 390393.

Bokhtiar, S.M. and Sakurai, K. (2004). Effect of organic manure and inorganic fertilizer on soil fertility and the productivity of sugarcane in Bangladesh. The Planter, Kualampur, 80: 443-452.

Chen, J.C.P. and Picon, R.W. (1972). Cane juice acidity versus sugar recovery. Sugar Journal, 34 (10): 25-27.

Choudhary, C.N, Sinha, U.P. (2001). Dry matter production, sugar yield and nitrogen recovery by sugarcane as influenced by concentrated organic manure, nitrogen and sulphur fertilization. Indian Journal of Agricultural Science, 71(1): 34-36.

Economics Survey, (2013). Department of Economics and Statistics, Government of India, 2013.

Ibrahim, H.S. (1979). Effects of fertilizers on sugarcane in the Sudan. Experimental Agriculture, 15(1): 107-111.

Jackson, M.L. (1973). Soil Chemical Analysis. Prentice Hall of India Private Limited, New Delhi.

Jamal, A., Ahmad, S.,Kumari, S.,Fazli, I.S., Rahman, R.U. and Adiu, M.Z. (2003). Nitrogen and sulphur nutrition enhances seed and oil yield of groundnut (Arachis hypogaea). Paper presented at $2^{\text {nd }}$ International Congress of Plant Physiology, 8-12 January, New Delhi, India, $395 \mathrm{pp}$.
Joshi, S. and Amodkar, V. (2000). Increase in cane yield and leafnutrient content due to sulphur application. Proceedings on Sugar Technology Association of India, $62:$ 6070.

Kaler, A.S., Mabry McCray, J., Alan L. and Wright \& John Erickson, E. (2017). Sugarcane yield and plant nutrient response to sulfur-amended Everglades histosols, 40 (2): 187-196.

Kumar, V., Dang, Y.P., Singh, J., Mehta, A. and Dhawan, S. (2004). Identification of phosphorus efficient sugarcane genotypes based on cane and sugar yield efficiency index. Indian Sugar, 53: 823-831.

Kumar, V., Varma, K.S. and Sagwal, O.P. (2003). Effect of continuous application of different levels of potassium on yield and juice quality of sugarcane and economic return. Indian Sugar, 52(11): 911-917.

Lakshmikantham, M., Narasimha Rao, G., Hanumantha Rao, P., Ramana Rao, P.V. and Narasimha Rao, P.V. (1970). Studies in crop logging of sugarcane. Andhra Pradesh Agricultural University Hyderabad.

Marschner, H. (1995). Mineral nutrition of higher plants $\left(2^{\text {nd }} E d n\right.$. $)$. Academic Press, London.

Meade, G.P. and Chen, J.P. (1977). Cave sugar hand Book $\left(10^{\text {th }}\right.$ Edn. $)$. John Wiley and Sons Inc, New York.

Natarajan, P. (1998). Yield maximization in seed cane by optimizing the plant population, age of nursery and nitrogen management. Ph.D., Thesis. Tamil Nadu Agricultural University.

Navnit Kumar, (2012). Productivity, quality and nutrient balance in spring sugarcane (Saccharum spp. hybrid complex) under organic and inorganic nutrition. Indian Journal of Agronomy, 57(1): 68-73.

Olsen, S.R., Cole, C.V., Watanabe, F.S. and Dean, L.A. (1954). Estimation of available phosphorus in soils by extraction with sodium bicarbonate. Circular-939. United States Department of Agriculture, Washington DC, USA.

Plucknett, D.L., Evenson, J.P. and Sanford, W.G. (1970). Ratoon cropping. Advances in Agronomy, 22: 285-330. 
Rakkiyappan, P. (1987). Effect of soil types and levels of N\&K on yield, quality and nutrient uptake of two sugarcane varieties (CoC 671 \& Co 6304), TNAU, Coimbatore.

Rohtash Kumar, and Singh, P.P. (1997). Effect of phosphorus and zinc nutrition on yield attributes of sugarcane in calcareous soil of foothill region of Uttar Pradesh. Indian Journal of Agronomy, 42(4): 702-704.

Sammuels, G. (1965). The response of sugarcane to fertilizer application as influenced by irrigation. Proceedings of the International Society of Sugarcane Technologist (ISSCT) 12: 10-14.

Sangwan, A., Kumar, V. and Duhan, B.V. (2010). Effect of potassium application on different forms of potassium in sugarcane soil and their relationship with cane yield. Indian Sugar, 60(12): 67-72.

Season and Crop Report of Tamil Nadu. (2015) Department of Economics and Statistics, Chennai-6.

Shukla, S.K. and Lal, M. (2007). Growth, quality and economics of plant and ratoon sugarcane (Saccharum spp. Hybrid complex) as influenced by does and sources of sulphur. Indian Journal of Agronomy, 52(2): 168-171.

Singh, A., Rao, S.P., Gupta, A.K. and Kushwaha, H.P. (1997). Effect of $P$ and $S$ application on yield, quality of nutrient content in sugarcane. Indian Sugar, 47(2): 33-37.

Sreelatha, T., Rama Lakshmi, Ch.S., Usha Rani, T. and Naidu, N.V. (2010). Integrated nitrogen management for better nitrogen uptake and yield in sugarcane. Indian Sugar, 60(5): 35-40.
Srinivas, D., Rao, B.R., Suresh, K., Vijayakumar, M. and Kishan Reddy, L. (2003). Influence of levels of nitrogen on the yield and quality of early maturing sugarcane varieties. Co-operative Sugar, 34(6): 479485.

Srivastava. T.K., Singh, A.K. and VishaKumari, V. (2013). Fertilizer best management practices in sugarcane. Indian Journal of Fertilizer, 9(4): 96- 107.

Subbiah, B.V. and Asija, G.L., (1956). A rapid procedure for estimation of available nitrogen in soils. Current Science, 25: 259-260.

Thangavelu, S. (2007). Zinc and sugarcane production-A Review. Indian Sugar, 57(5): 39-46.

Tiwari, K.N. (2002). Balanced fertilization for food security. Fertilizer News, 47(11): 113-122.

Tyagi, S., Saini, S.K. and Kumar, V. (2011). Yield and soil nutrient balance of sugarcane (Saccharum officinarum) plant-ratoon system under integrated nutrient management. Indian Journal of Agronomy, 56(3): 247-253.

Walkley, A. and Black, C.A. (1934). An examination of method for determining soil organic matter and a proposed modification of the chromic acid titration method. Soil Science, 37: 93-101.

Williams, C.H. and Steinbergs, A. (1959). Soil sulphur fractions as chemical indices of available sulphur in some Australian Soils. Australian Journal of Agricultural Research, 10: 340-352.

\section{How to cite this article:}

Vijayakumar, M., M. Thirunavukkarasu, R. Dhanasekara Pandian and Mahendran, P. P. 2020. Enhancement of Sugarcane Productivity through STCR based Balanced Fertilization. Int.J.Curr.Microbiol.App.Sci. 9(05): 3433-3449. doi: https://doi.org/10.20546/ijcmas.2020.905.408 